Provided for non-commercial research and education use. Not for reproduction, distribution or commercial use.

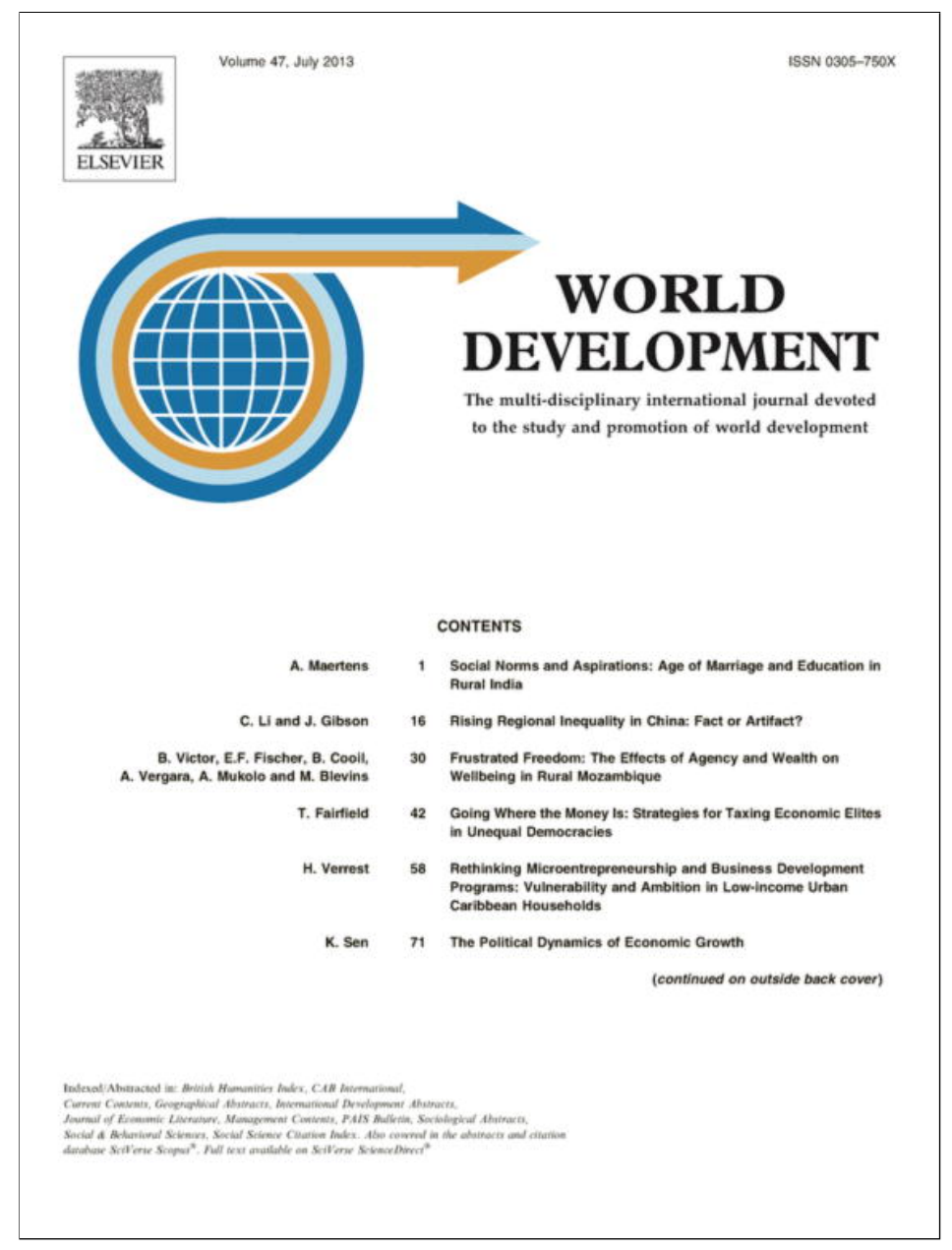

This article appeared in a journal published by Elsevier. The attached copy is furnished to the author for internal non-commercial research and education use, including for instruction at the authors institution and sharing with colleagues.

Other uses, including reproduction and distribution, or selling or licensing copies, or posting to personal, institutional or third party websites are prohibited.

In most cases authors are permitted to post their version of the article (e.g. in Word or Tex form) to their personal website or institutional repository. Authors requiring further information regarding Elsevier's archiving and manuscript policies are encouraged to visit:

http://www.elsevier.com/authorsrights 


\title{
The Political Dynamics of Economic Growth
}

\author{
KUNAL SEN * \\ University of Manchester, UK
}

\begin{abstract}
Summary. - We argue that an understanding of the political drivers of economic growth needs an explanation of the political dynamics around the transition from one growth phase to another, and that the political drivers of early stage growth accelerations are different from that of growth maintenance. Informal institutions are likely to play a role in growth acceleration, while formal institutions of credible commitment, the provisioning of public goods and the overcoming of co-ordination failures will be more important in growth maintenance. We present empirical evidence drawn from country case-studies and cross-country econometric analysis that provides support to our theoretical propositions.

(c) 2013 Elsevier Ltd. All rights reserved.
\end{abstract}

Key words — political dynamics, political settlements, economic growth, institutions, growth phases

\section{INTRODUCTION}

The process of economic growth and why there are such significant differences in living standards across countries is one of the most important and challenging areas of research in economic development. An early tradition in the very large literature that exists on the determinants of economic growth was mostly focused on understanding the proximate determinants of economic growth, and in particular, the role of human and physical capital accumulation, technological change, and productivity growth in explaining economic growth. However, as North and Thomas (1973) noted, such proximate determinants or correlates of economic growth "are not causes of growth; they are growth" (p. 2). A more recent literature has gone beyond these proximate determinants and attempted to understand the fundamental causes of economic growth- "the factors potentially affecting why societies make different technology and accumulation choices" (Acemoglu, 2009, p. 20).

Institutions and geography are widely regarded as the two most important fundamental causes of economic growth (Acemoglu, Johnson, \& Robinson, 2001; Sachs, 2003). While these two factors are not necessarily mutually exclusive causes of economic growth, a large empirical literature has shown that institutions - understood as the formal and informal rules that constrain economic and social behavior-trump geography as the dominant cause of long-run improvements in standards of living. While this literature identifies the causal effect of regulations, laws and norms on economic incentives, and in particular, on the incentives to invest in the technology, physical capital and human capital that are proximate determinants of economic growth, it also recognizes that these economic institutions are in large part politically determined, and ultimately reflect choices made and decisions taken by society at large or by some powerful groups in the society. A very new literature has been analyzing why in certain political contexts, growth-enhancing economic institutions emerge and why we see the persistence of growth-impeding economic institutions in many developing countries for long periods of time.

In this paper, we assess what we know (and what we do not know) about the role of political factors in explaining why some countries economies grow faster than others. We begin with a fresh look at the "stylized facts" of economic growth. We identify an important limitation in the past literature on economic growth in that their focus on rates of average growth of per capita income has obscured the fact that most countries observe dramatic fluctuations in growth of per capita income. Most developing countries tend to observe stop-go growth episodes, with growth accelerations followed by growth decelerations or collapses. We argue that an understanding of the political drivers of economic growth needs an explanation of the political dynamics around the transition from one growth phase to another - that is, the political determinants of growth accelerations, growth maintenance, and growth declines/collapses. We then propose a conceptual framework to understand the political channels of economic growth around the transitions from one growth phase to another phase. In developing this framework, we argue that the political drivers of early stage growth accelerations are different from the political drivers of growth maintenance. Next, we use this framework to review the recent theoretical literature on the political determinants of economic growth and relate our conceptual framework to this literature. We then review the empirical basis of our approach to the politics of economic growth, and find suggestive evidence both in qualitative case-studies and in the cross-country econometric literature that supports the main propositions of our approach.

The rest of the paper is structured as follows. We first set out the "stylized facts" of economic growth in Section 2. In Section 3, we sketch out our preferred framework by which to understand the "stylized facts" of economic growth. In Section 4, we review the theoretical literature on the political and institutional determinants of growth through the lens of our framework. Section 5 surveys the empirical literature on the political and institutional determinants of economic growth as well as provides further evidence to support our conceptual approach. Section 6 concludes, and proposes a set of issues that should inform future research on the political drivers of economic growth.

\footnotetext{
* This paper is part of the research undertaken by the UK-DFID funded Effective States and Inclusive Development (ESID) research centre, based in the University of Manchester. I am grateful to Sam Hickey, Adrian Leftwich, Lant Pritchett, Selim Raihan and three anonymous referees for their extensive comments, and for discussions with Sabyasachi Kar. Purnima Purohit provided effective research assistance. The usual disclaimer applies. Final revision accepted: February 28, 2013.
} 


\section{STYLIZED FACTS OF ECONOMIC GROWTH}

The standard definition of economic growth is that it is a sustained increase in per capita incomes over a sufficiently long period. The Commission for Growth and Development (CGD, 2008), a multi-donor initiative to study the causes of economic growth, identifies only thirteen countries which have experienced high, sustained economic growth (defined as an average of $7 \%$ growth of per capita income or more over 25 years or more). These thirteen success stories are listed in Table 1. Two of these countries are developed countries (Japan and Malta), and one is oil rich (Oman). This leaves only 10 countries from the developing world that have experienced sustained growth in the post-World War II period: Botswana, Brazil, China, Hong Kong, Indonesia, Korea, Malaysia, Singapore, Taiwan, and Thailand. Figure 1 provides the plots of per capita Gross Domestic Product (GDP) (in constant 2005 US Purchasing Power Parity (PPP) dollars) for the 10 developing countries from 1960 to 2008. It is clear that the increase in per capita income for most of these countries (with the exception of Brazil) follows a linear growth process, and that income grew more or less continuously for these countries (except for the period of the 1997 financial crisis, which affected economic growth in countries such as Indonesia, Korea, and Thailand, with Indonesia's growth showing a distinct slow-down since 1997).

There is one important limitation of CGD's approach in identifying economic growth successes, which is also evident in the wider empirical literature on economic growth. CGD's approach of classifying growth successes by high rates of average growth of per capita income misses the point that most countries observe dramatic fluctuations in growth of per capita income. Very few developing countries meet the criterion of sustained high rates of growth - most developing countries tend to observe stop-go growth episodes, with growth accelerations followed by growth decelerations or collapses. As Jones and Olken (2008) point out, "almost all countries in the world have experienced rapid growth lasting a decade or longer, during which they converge toward income levels in the United States. Conversely, nearly all countries have experienced periods of abysmal growth. Circumstances or policies that produce 10 years of rapid economic growth appear easily reversed, often leaving countries no better off than they were prior to the expansion" (p. 582). Therefore, long-run growth averages within countries often mask distinct periods of growth success and growth failure, and "the instability of growth rates makes the talk of the growth rate almost meaningless" (Pritchett, 2000, p. 247). Growth experiences differ over time within a country almost as much as they differ among countries, and identical average growth rates can mask very distinct growth paths (Jerzmanowski, 2006). ${ }^{1}$

To illustrate our point about the very different growth phases that may characterize economic growth for a particular country over a period of time, we present plots of GDP per capita for a random sample of 10 developing countries drawn from Africa, Asia, and Latin America (see Figure 2). The evolution of GDP per capita shows distinct patterns across the 10 countries, and more importantly, within these countries. For example, Argentina has seen both periods of high growth and periods of growth declines. Ghana and Tanzania have seen a prolonged period of stagnation in the $1980 \mathrm{~s}$ and 1990 s, followed by positive growth in the 2000s. Malawi and Zambia have observed prolonged periods of growth collapses. In comparison, Uganda shows a significant growth collapse in the 1970 s, followed by rapid growth since the 1980s. It was the reverse in the Congo, with growth accelerating in the 1960 and 1970s, and then stagnating since the mid-1980s. In the case of The Philippines, there were multiple growth phases - there was steady economic growth in the 1960s and early 1970s, followed by a growth collapse in the late 1970s and then stagnation in the 1980s and early 1990s, with growth recovering in the 2000s. Tanzania witnessed a long period of stagnation for three decades in the 1970 s to 1990 s, with rapid economic growth in the 2000s. Economic growth was low in India till the late 1970 s, with a steady acceleration since the early 1980 s.

Thus, growth phases vary across time and space - the same growth phase does not characterize countries in the same region and in the same period, and countries which are similar in some respects (such as Ghana and Uganda) show very different growth phase switches. This tells us that exogenous factors such as oil shocks or terms of trade declines may not be causal to growth phase switches, or at least, that their effects of economic growth may be mediated by country-specific variables. The analytical challenge here is to understand what leads to growth accelerations in some countries and not in others, and why do some countries maintain economic growth for extended periods, while in other countries, economic growth declines or collapses after initially accelerating. What explains the likelihood of a country switching from one growth phase

Table 1. Success stories of sustained, high growth, as identified by the Commission for Growth and Development (CGD, 2008)

\begin{tabular}{|c|c|c|c|}
\hline \multirow{2}{*}{$\begin{array}{l}\text { Economy } \\
\text { Botswana }\end{array}$} & \multirow{2}{*}{$\begin{array}{c}\text { Period of high growth }{ }^{* *} \\
1960-2005\end{array}$} & \multicolumn{2}{|c|}{$\begin{array}{l}\text { Per capita income at the } \\
\text { beginning and } 2005^{* * *}\end{array}$} \\
\hline & & 210 & 3,800 \\
\hline Brazil & $1950-80$ & 960 & 4,000 \\
\hline China & 1961-2005 & 105 & 1,400 \\
\hline Hong Kong, China ${ }^{*}$ & $1960-97$ & 3,100 & 29,900 \\
\hline Indonesia & $1966-97$ & 200 & 900 \\
\hline Japan $^{*}$ & $1950-83$ & 3,500 & 39,600 \\
\hline Korea, Rep. of* & $1960-2001$ & 1,100 & 13,200 \\
\hline Malaysia & 1967-97 & 790 & 4,400 \\
\hline Malta ${ }^{*}$ & $1963-94$ & 1,100 & 9,600 \\
\hline Oman & $1960-99$ & 950 & 9,000 \\
\hline Singapore $^{*}$ & $1967-2002$ & 2,200 & 25,400 \\
\hline Taiwan, China ${ }^{*}$ & 1965-2002 & 1,500 & 16,400 \\
\hline Thailand & $1960-97$ & 330 & 2,400 \\
\hline
\end{tabular}

Source: CGD (2008)

*Economies that have reached industrialized countries' per capita income levels.

${ }^{* *}$ Period in which GDP growth was $7 \%$ per year or more.

In constant US\$ of 2000 


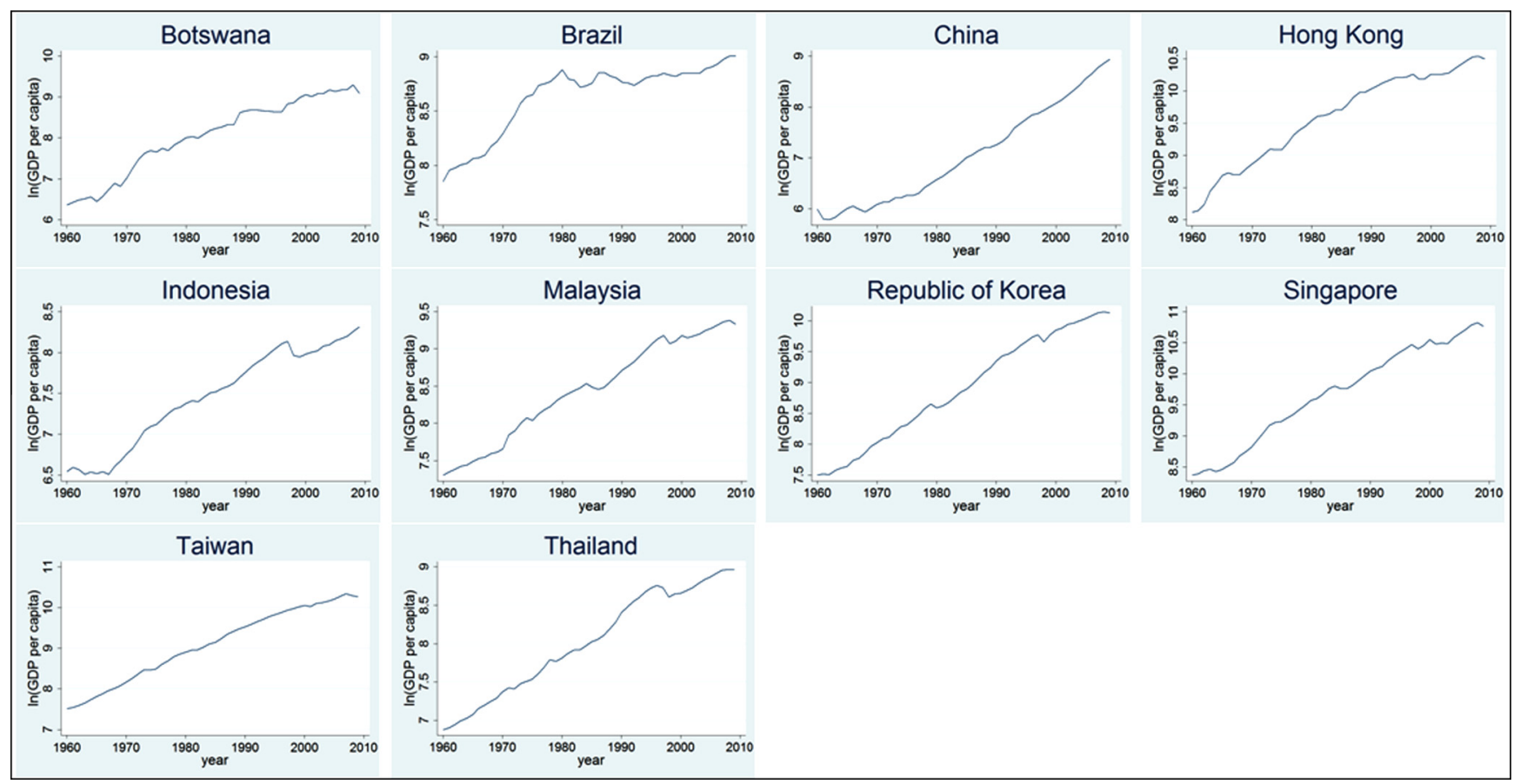

Figure 1. The 10 growth successes from the developing world. Note: Log (In) PPP GDP per capita, 1960-2010, at 2005 constant prices.

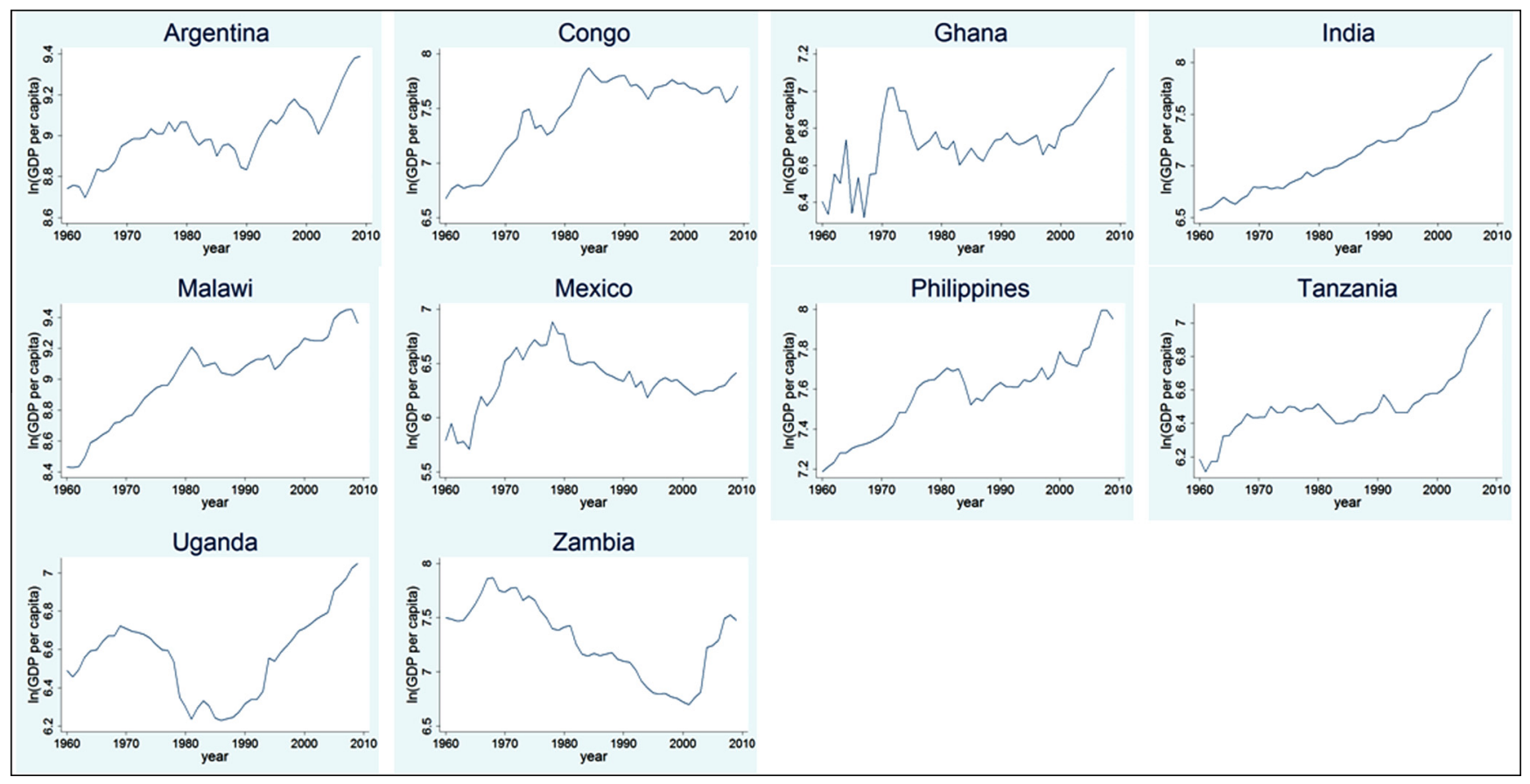

Figure 2. Growth phases in a sample of countries. Note: Log (In) PPP GDP per capita, 1960-2010, at 2005 constant prices.

to another growth phase, and what is the role of political factors in these growth traverses?

To fix our ideas on transition paths around growth phases, we provide a simple sketch of these transition paths in Figure 3 below. Using a rough and ready way to demarcate growth phases, we classify them into four categories: (i) a growth phase which we call "miracle growth" where the average increase in per capita income is 7\% per annum or more; (ii) a growth phase which we call "stable growth," where the average increase in per capita income is between two and 7\% per annum; (iii) a growth phase which we call "stagnant growth," where the average increase in per capita income is between 


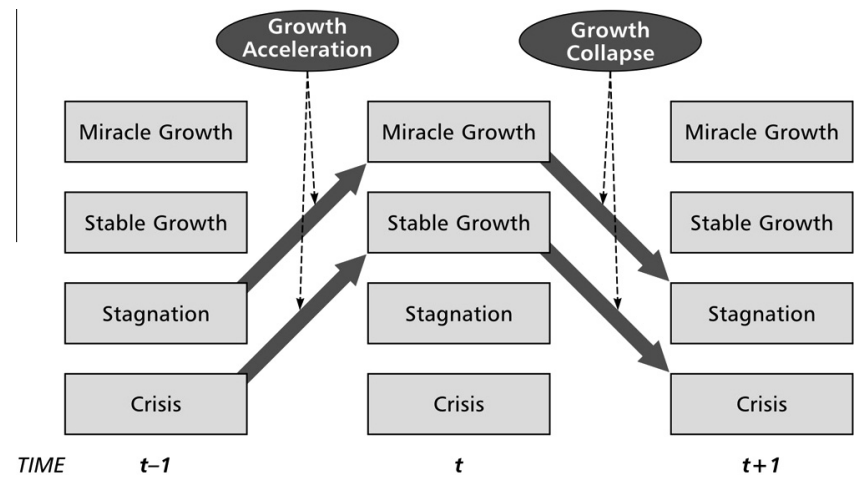

Figure 3. Transition paths between growth phases.

zero and $2 \%$ per annum; and (iv) a growth phase we call "growth crisis" where the average change in per capita income is negative. ${ }^{2}$

There are three points to note from Figure 3. Firstly, most, if not all, of the countries that the CGD considers as growth successes will be those in the top half of the figure (miracle growth $=>$ miracle growth), where a country is persistently in a miracle growth phase. Secondly, in understanding transitions between growth phases, we should not only be interested in countries which make the move from stagnant/crisis growth to miracle growth but also countries which make the transition from negative growth to stable growth as well. The latter type of growth transition is important and may have significant implications for the country's welfare and its ability to move out of a situation where the living standards of its citizens are declining, to a situation where they are improving. Thirdly, while much of the literature has concentrated on the causes of miracle growth and the maintenance of such growth, Figure 3 makes clear that our understanding of the causes of miracle growth will not be complete if we do not understand why some countries persistently remain in miracle/stable growth phases while others suffer growth collapses. Clearly, the avoidance of the factors that lead to growth collapses or declines is the reason why some countries see persistent high economic growth over extended periods of time.

If the emphasis in our understanding of economic growth in developing countries should be less on the determinants of long-run average economic growth and more on the determinants of switches in growth phases, it would be necessary for us to understand the political dynamics around the transition from one growth phase to another, and the political economy determinants of growth accelerations, growth maintenance, and growth declines/collapses. The overarching research question for us to address would be to understand what determines political transitional dynamics around growth phase traverses - the move from one growth phase to another growth phase. In the next section, we sketch out a framework which makes an attempt in this direction and that we will use as a way to embed our review of the theories and empirical evidence on the politics of growth within the context of such a research question.

\section{THE POLITICAL CHANNELS TO ECONOMIC GROWTH}

By definition, economic growth is an outcome of increase in capital accumulation and increases in productivity or technological progress. But what are the political channels by which capital accumulation and/or productivity increases occur? Do these political channels play out differently across the different phases of economic growth-from growth acceleration to maintenance/sustenance? In this section, we sketch out a framework for understanding the political channels of growth, and especially in the transition from one growth phase to another.

We have already noted in the previous section that the "stylized facts" of economic growth show the high volatility of economic growth, and that many countries frequently switch from one growth phase to another-from growth acceleration to growth decelerations after a period of high growth, followed by another growth acceleration at a later date. Therefore, growth accelerations and growth declines can occur at any stage of economic development, and even countries with medium to high levels of per capita income may suffer a growth deceleration at any point in time. For the purposes of our framework, we distinguish between early stage and later stage growth accelerations - early stage growth accelerations occur when the country is at a very early stage of economic development and has had a prolonged period of stagnation or negative growth prior to the growth acceleration while late stage growth accelerations may occur after the country has experienced a previous growth acceleration and observed positive growth for some time, followed by a growth deceleration.

We identify three distinct political channels to growth. ${ }^{3}$ The first is credible commitment by the state, or agents of the state (Grief, 2006). ${ }^{4}$ That is, the state needs to credibly commit to potential and current investors that it will not expropriate most or all of the profits that may accrue from the production process or the means of production themselves. By committing to not expropriating rents over and above which may be considered to be "fair," the state can ensure that investors commit to the investment decision and engage in production, so that rents can be generated through the production process. This commitment needs to be seen as credible by investors in that they believe that the state or its agents will not renege on its implicit or explicit promise not to expropriate all or most of the rents accruing from the production process in the future, especially after investment decisions involving sunk costs in fixed capital have been taken (Bardhan, 2005). Investors also need to commit to share a part of their rents to the state (or its constituents, such as politicians) and when states raise revenues from taxes, to pay the state the necessary taxes.

Credible commitment can be seen as both a necessary and sufficient condition for capital accumulation to take place or for entrepreneurs to make the necessary investments in productivity enhancing changes in their enterprises. Most investment activities take time and there are lags between the time-period when investment in land and machinery is made, and the time-period when profits can be obtained from the sale of the product in the market. Investment decisions are by their nature lumpy and may have large sunk costs - that is, the costs of certain investments cannot be recovered in full if the investment decision turns out to be less profitable than anticipated (Dixit \& Pindyck, 1994; Pindyck, 1991). By credibly committing ex ante to not extracting most of the proceeds from the investment decision, the state provides the incentive for the entrepreneur to make the investment and production decision and can extract a part of the proceeds from the investment ex post (Rodrik, 1991). In this sense, credible commitment is incentive compatible both for the state and the entrepreneur. However, it follows from the nature of credible commitment that the state has to take a reasonably long view in that reneging on the commitment not to fully extract the rents from investment in one period can lead to a loss in credibility on 
the part of the state, and for investors not to trust the state when it comes to future investment decisions, leading to a fall in investment, and consequently, in a decline in rent extraction in future periods.

Credible commitment can be obtained through both formal and informal institutions. Formal institutions such as laws which prohibit the expropriation of private property (which investors believe will be implemented), courts that provide sanctions against the firm's customers when there is a nonpayment of dues, and bankruptcy procedures which protect financiers such as bondholders when a firm enters into bankruptcy are all examples of formal institutions of credible commitment.

But informal institutions such as kinship structures, social norms, and patron-client networks can also act as institutions of credible commitment, especially in environments where formal institutions do not exist or are not well-functioning (Dixit, 2009). For example, in a patron-client network, where the patron is the politician and the client is the domestic entrepreneur, the politician may protect the entrepreneur and provide him or her with access to funds and certain privileges (such as licenses for production or imports) in return for the rents that accrue from production which may be used in part for financing the political machinery. Entrepreneurs too will have an incentive to find political patrons who may be keen to protect them, in exchange for economic and political support. Therefore, the existence of informal institutions of credible commitment can be both necessary and sufficient for an episode of early stage growth acceleration, especially in a low income country where formal institutions have not developed or do not function effectively. As long as informal institutions that exist can address at least in part the credible commitment problem in the investment decision, entrepreneurs will be willing to invest, and economic growth will result. 5

A second political channel to economic growth is the provision of public goods. ${ }^{6}$ Among the determinants of economic growth that have been identified in the empirical growth literature are public goods such as primary and secondary education and provision of health services that are both available to a broad cross-section of the population, and infrastructure such as roads and electricity, that are seen as being crucial enabling factors for economic growth to occur (Barro, 1991; Benhabib \& Speigel, 1994; Bloom, Canning, \& Sevilla, 2004; Pedroni \& Canning, 2008; Strauss \& Thomas, 1998). The literature on the provision of public goods generally see these goods being produced when the state has enough capacity both to raise taxes to finance large scale provision of public goods and to administer the effective delivery of these goods. The dimensions of state capacity that may matter here are bureaucratic and infrastructural power - the capacity of the state to implement decisions and exert its authority over the national territory (Evans, 1995; Soifer, 2008). Clearly, the more capable the state is in its ability to raise taxes and in its ability to use these taxes to provide high quality "productive" public goods to the majority of the population, the larger will be the growth-enhancing effects of public goods provision. As Evans and Rauch (1999) find, an increase in half a standard deviation of the "Weberian score" of bureaucratic capacity is worth a 26\% increase in GDP from 1970 to 1990 . But bureaucratic and infrastructural power need a certain degree of bureaucratic professionalism, and it is more likely that the formal institutions that underpin such bureaucratic professionalism (such as meritocratic recruitment and merit based promotion) will emerge later in the growth process. Therefore, the provision of public goods will be less important as a political channel to growth accelerations and may be more important for growth maintenance.
The third political channel to growth is the overcoming of co-ordination failures in investment decisions. We distinguish between market size related coordination failures on one hand and information and spillover related co-ordination failures on the other (Hoff, 2000). Market size related coordination failures occurs when the size of the market is a constraint on the growth of domestic industry. With a small size of the domestic market and when world trade is not free and costless, firms may not be able to generate enough sales to make adoption of increasing returns technologies profitable, limiting the possibility of industrialization and structural transformation of the economy (Murphy, Shleifer, \& Vishny, 1989). Information relation co-ordination failures result from the high costs of collecting and processing information for new products, technologies, and industries in low income countries. By investing in new information collection and processing and making information about the relevant new industries freely available to firms, the state can play a facilitating role in the introduction of new products and the move to new industries, and as a consequence, in bringing about structural change and technological upgrading in the economy (Lin \& Monga, 2010). Spillover related co-ordination failures also result from the fact that private returns to investment in sectors that offer the potential of dynamic comparative in low income countries may be less than social returns, as firms need to go through a learning process to build the capabilities to become competitive in new industries (Whitfield \& Therkildsen, 2011). Since this learning process may involve substantial financial losses at least at the initial stage, the private return to such investment may well be negative, even if the investment may lead to significant positive spillover effects and the building up of social and human capital. Risk averse entrepreneurs with low wealth endowments may not be willing to invest in such investments that have high sunk costs and prefer to invest in activities with a high short-term possibility of profits but which offer less possibilities for technological upgrading.

The divergence of the private and social returns to investment may be particularly evident in more modern manufacturing activities or in knowledge-based services as compared to unskilled labor intensive manufacturing or primary commodity production. As the economy moves into these modern sectors, spillover related co-ordination failures would become more pronounced and there would be a need for the state to play a coordinating role in directing scarce investible funds and limited foreign exchange (to purchase imported capital goods and technology from abroad) to the most productive firms and facilitate the upgrading and diversification of individual firms (Lin \& Monga, 2010).

But the overcoming of information and spillover coordination failures needs both a political elite that is committed to a long-term vision of economic development (since the growth payoffs to technological upgrading and industrial diversification may take time to occur) and the presence of an economic bureaucracy that is staffed by relatively competent individuals who are insulated from the pressures of special interests. Such bureaucracies are characterized by a high degree of well institutionalized and organizationally consistent career ladder which binds them to corporate goals while simultaneously allowing them to acquire the expertise necessary to perform effectively (Evans, 1995). The relative autonomy of the bureaucracy allows them to intervene selectively in favor of certain firms, sectors, and industries and to provide both incentives to capitalists and to discipline them (Amsden, 1989; Wade, 1990). Based on the East Asian successes in how governments in these countries successfully overcame coordination failures, Evans $(1995,2011)$ has argued that another important 
attribute of bureaucracies in these countries that allowed them to address coordination failures effectively was their "embeddedness," that is, "the dense set of concrete interpersonal ties that enabled specific agencies and enterprises to construct joint projects at the sectoral level" with local capitalists (Evans, 2011, p. 47). Both embeddedness and autonomy were essential features of the state's ability to address coordination failures effectively in the East Asian "growth successes." As Evans (2011), argues, "avoiding capture and being able to discipline entrepreneurial elites is a defining feature of the 'embedded autonomy' of East Asian developmental states, distinguishing them from less successful states in Asia and Africa" (p. 47).

How important would the overcoming of coordination failure be as a political channel to growth across different growth phases? Our discussion of how coordination failures may arise in developing countries indicates that different types of coordination failures would be apparent at different stages of the growth process. Market size related co-ordination failures would be more important at an early stage of structural transformation when the economy is making the move from agriculture to light and basic manufacturing. Particularly in the early stages of industrialization, the state needs to ensure that simultaneous industrialization of many sectors can be profitable even when it may not be profitable for each sector to industrialize alone (Murphy et al., 1989; Rosenstein-Rodan, 1943). Large scale public investment in infrastructure, for example, will lead to lower transport costs and/or an increase in aggregate demand that can provide the impetus for economic growth and early stage industrialization. Thus, the overcoming of market size related co-ordination failures could be an important determinant of an early stage growth acceleration. However, the demands on state capacity to overcome such co-ordination failures would be less intensive, than the case of information and spillover related co-ordination failures that are more likely to be evident in the later stage of structural transformation when the economy has started the transition from manufacturing activities that are less labor intensive and technologically less sophisticated to more complex goods.

Thus, the degree of state capacity needed in overcoming information and spillover related coordination failures will be higher than that needed for market related co-ordination failures. As we have argued earlier, the level of capacity and autonomy of the bureaucracy that may be needed to address the complex interventions necessary for resolving all but the most basic coordination failures would be more likely to emerge at a later stage of the growth process. The ability of the state to resolve information and spillover related coordination failures may play a causal role in why some states cannot successfully transform their economies to more productive and technologically advanced activities. This may also explain why some countries are able to maintain high growth if they are able to successfully transform their economies, while growth dies out in other countries which cannot manage this transformation. ${ }^{8}$

We provide a sketch of how the relative importance of the three political channels in the transition from one growth phase to another in Figure 4 (to simplify the diagram, we collapse the miracle and stable growth phases into one phase, and stagnation and crisis growth phases into another phase). As shown in the figure, the first political channel we discussinstitutions of credible commitment - may be a necessary and sufficient channel to early stage growth accelerations while contributing to growth maintenance as well. Informal institutions of credible commitment (around self-sustaining patronclient networks that are incentive compatible to both agents of the state and investors) are likely to play a more important

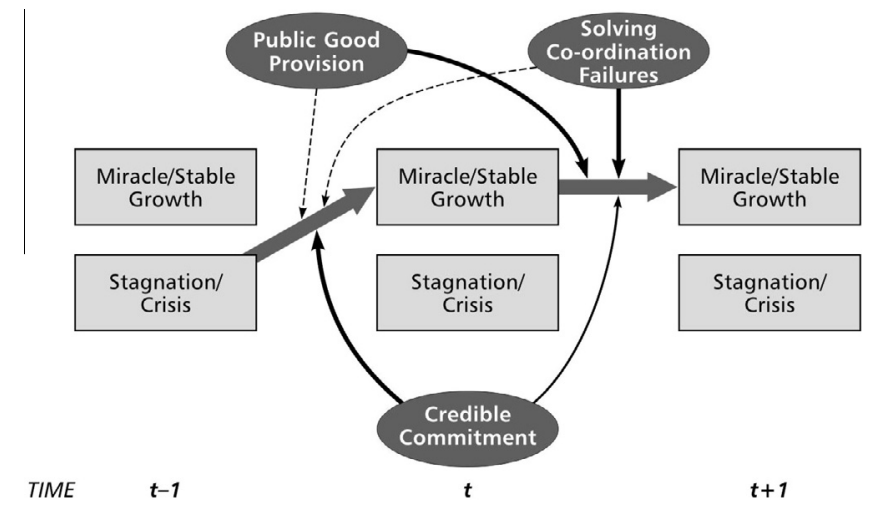

Figure 4. Political channels to growth along transition paths.

role in growth accelerations when a country is in a stage of economic development when formal institutions have not emerged or where they exist, are nonfunctioning (or not enforced), while formal institutions will be more important in growth maintenance. The second political channel we discuss - the provision of public goods - would be more important in growth maintenance and in the avoidance of growth collapse, though it can also play some role in growth accelerations. The thickness of the arrows linking this channel to the different phases of growth shows the relative importance of this channel for the growth maintenance phase as compared to the growth acceleration phase. Finally, as shown in the figure, the third political channel we discuss - the overcoming of coordination failures-would be important in the growth maintenance phase, but can play a role in growth acceleration as well. ${ }^{9}$

\section{A REVIEW OF THE THEORETICAL LITERATURE}

In this section, we will review the literature on the politics of economic growth, and assess the strengths and weaknesses of the major theoretical and empirical literature on the politics of economic growth. Specifically, we will ask the following two questions of the literature:

(i) To what extent can these theories explain the movement between different growth phases that we set out in Section 2 ?

(ii) To what extent do these theories provide an analytically coherent account of economic growth that address the political channels of growth as discussed in Section 3?

Our literature review is deliberately selective - we review the specific theories that have been influential in the recent literature on economic growth, and that illustrate our arguments around the political dynamics of growth phase switches. The two major theoretical bodies of literature that we discuss are the work of (a) Daron Acemoglu and James Robinson (Acemoglu-Robinson), and (b) Mushtaq Khan. We begin with a review of the work of Acemoglu-Robinson. ${ }^{10}$

\section{(a) The politics of growth maintenance: Acemoglu-Robinson and inclusive institutions}

As with much of the recent literature on the politics of economic growth, Acemoglu-Robinson (AR)'s starting point is the premise that institutions, defined as "the rules of the game or more formally, the humanly devised constraints that shape 
human interaction" (North, 1990, p. 3) are the fundamental cause of economic growth. The set of institutions that matter for broad-based economic growth, according to AR, are inclusive economic institutions and inclusive political institutions (Acemoglu \& Robinson, 2008, 2012). Inclusive economic institutions are secure property rights for the majority of the population (such as smallholder farmers and small firms), law and order, markets that are open to relative free entry of new businesses, state support for markets (in the form of public goods provision, regulation and enforcement of contracts) and access to education, and opportunity for the great majority of citizens. Inclusive political institutions are political institutions that allow broad participation of the citizens of the country and uphold the rule of law, and place constraints and checks on politicians along with the rule of law. ${ }^{11}$ In contrast to the growth-enhancing effects of inclusive economic and political institutions, AR argue that extractive economic institutions such as insecure property rights and regulations that limit entry to markets and extractive political institutions that concentrate power in the hands of a few with limited checks and balances are not likely to lead to broad-based and sustained economic growth (that is, growth can occur for some time under these institutions but is not likely to last and will benefit a narrow set of elites rather than the majority of the population).

But what determines the set of economic and political institutions prevailing in the country at a particular point of time? Economic institutions are not distribution neutral: they not only determine the aggregate growth potential of the economy but also the distribution of resources in the country. This implies that economic institutions are politically determined, as the prevalent power relations will determine which set of economic institutions are more likely to emerge. A similar argument can be made for political institutions, and AR argue that these are determined by political power of different groups in society. Political power can be both de jure and de facto. De jure political power refers to power that originates from the political institutions in society. De jure political institutions determine the constraints on and the incentives of key actors in the political sphere and could be both formal (that is, whether the political system is democratic or autocratic) or informal (that is, the set of informal constraints on politicians and political elites). De facto political institutions, on the other hand, originate from the possibility that important social and political groups which hold political power may not find the distributions of benefits allocated by de jure political institutions and by economic institutions acceptable to them, and may use both legal and extra-legal means to impose their wishes on society and try to change these institutions (for example, they may revolt, use arms, co-opt the military, or undertake protests).

AR argue that the degree of de facto political power originates from the ability of some groups to solve their collective action problem and from the economic resources available to the group (which determines their capacity to use force against other groups). In the ultimate analysis, therefore, the initial distribution of economic resources and the nature of de jure political institutions determine both de jure and de facto political power and these in turn determine the set of economic institutions and political institutions that are likely to emerge in the economy, and which in turn determine economic performance and the distribution of resources that are compatible with the distribution of political power. This can be seen in the following schematic representation in Figure 5.

An important implication of AR's theory is that extractive institutions which lead to poor economic performance may

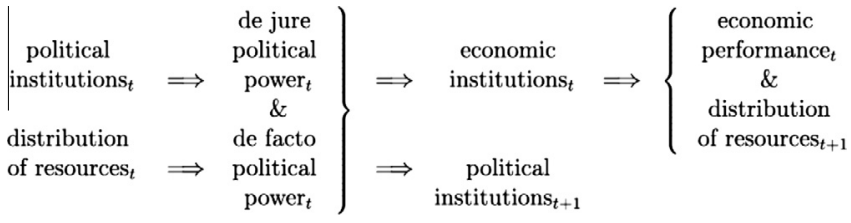

Figure 5. The evolution of political and economic institutions in Acemoglu and Robinson's theory of economic growth. Source: Acemoglu and Robinson (2008).

persist over time, and economic growth may stagnate in a country for many years as a consequence. Since the distribution of political power determines the evolution of economic and political institutions, political elites who hold power will always have an incentive to maintain the political institutions that give them political power, and the economic institutions that distribute resources to them. Furthermore, the initial distribution of resources allow elites who have access to these resources to increase their de facto political power, allowing them to push for economic and political institutions favorable to their interests, reproducing the initial disparity in political power (Acemoglu, Johnson, \& Robinson, 2005). Therefore, there will be a persistence of extractive economic and political institutions in societies with such institutions, since the elites who benefit from these institutions would not have an incentive to change them. Conversely, inclusive economic and political institutions will be more likely to prevail, once they emerge, as with the emergence of such institutions (e.g., democratization and secure property rights for the majority of the population), strong economic performance will be likely to result, reinforcing the welfare enhancing effects of these institutions and allowing states to become more credible via greater legitimacy to the commitment of these institutions.

But what explains the switching from one growth phase to another; say, from stagnant growth to miracle growth? AR argue that while extractive institutions tend to persist, change is possible, with time, institutional drift may occur, leading to a critical juncture where there may be institutional divergence. This is shown in Figure 6 below.

Many factors can contribute to this divergence. For example, new economic elites may emerge who challenge the existing balance of power and demand change in economic institutions from extractive to more inclusive institutions. There is also the possibility of revolt from citizens excluded from current political institutions, and the elite may respond with greater political pluralism. AR view these critical junctures as "stochastic" and therefore, to a large extent, exogenous, and they state that it is not clear "under what circumstance political equilibria that lead to economic growth will arise" (AR, 2008, p. 10). Therefore, it is not clear how a country will move from a bad political equilibrium associated with growth stagnation/crisis to a good political equilibrium associated with stable or miracle growth, where the political drivers of this move is endogenously determined, and not due to external events or to exogenous factors.

$\begin{array}{rrr}\text { institutions }_{t} & \underset{\mathrm{drift}}{\longrightarrow} \text { institutions }_{t+1} & \longrightarrow \\ & \nearrow \\ \text { critical juncture } & \text { institutional }\end{array}$

Figure 6. Institutional change in Acemoglu-Robinson's theory of economic growth. Source: Acemoglu and Robinson (2012). 
The political channels that are evident in AR's theory of growth are formal institutions of credible commitment (as in the rule of law that leads to the security of property rights) and public good provision. There is less recognition in their theory of the important role the state can play in overcoming coordination failures, and that the emergence of formal institutions of credible commitment and the provision of high quality public goods may not be enough to bring about the structural transformation that has been evident in the successful cases of economic growth in East Asia. AR's theory is more a theory of growth sustenance (and by association, also a theory of long-term growth stagnation) than a theory of growth acceleration or of growth collapse. Once growth has ignited in a country, the emergence of inclusive economic and political institutions may lock in the growth process, and also by implication, broaden the process of growth to make economic growth inclusive. Also, while AR do not directly state that the inclusive economic and political institutions they take to be correlated with sustained economic growth are formal institutions, the specific examples they provide of inclusive economic institutions such as contract enforcement and state regulation of markets and inclusive political institutions such as the rule of law for all citizens suggest that these are more likely to be formal institutions.

This also suggests that AR's theory of growth may be more relevant in the understanding of growth maintenance rather than early stage growth acceleration. The formal institutions that AR take to be crucial to economic growth need a sufficient level of state capacity for enforcement and for their effective functioning, and these enforcement capabilities (and the commitment of the ruling elite to enforce these institutions) are unlikely to be observed in the very early stages of economic growth when growth has begun to accelerate. To understand the political drivers of growth acceleration, we need a theory that can help us understand how economic growth occurs even without the presence of well-functioning formal institutions. We now discuss the work of Mushtaq Khan which, as we will argue, provides such a theory.

\section{(b) The political foundations of growth accelerations: Mushtaq Khan and patron-client networks}

Like AR, Khan starts with the proposition that institutions are the fundamental cause of economic growth (Khan, 2010). Like AR, Khan takes institutional performance to be a function of the distribution of power between important groups in society. Khan argues that the political settlement-defined as "the interdependent combination of a structure of power and institutions at the level of a society that is mutually 'compatible' and also 'sustainable' in terms of economic and political viability" - is the key determinant of institutional performance and consequently, economic growth. Khan defines power as holding power - that is, "how long a particular organization can hold out in actual or potential conflicts against other organizations or the state" and where holding power is "a function of a number of characteristics of an organization, including its economic capability to sustain itself during conflicts, its capability to mobilize supporters to be able to absorb costs and its ability to mobilize prevalent ideologies and symbols of legitimacy to consolidate its mobilization and keep its members committed" ((Khan, 2010, p. 20). The relationship between holding power and institutions is two way. The configuration of holding power at the level of society is supported by a range of formal and informal institutions that reproduce and sustain the specific configuration of relative power between organizations by enabling a consistent set of economic benefits to be created and allocated. In turn, relative power determines which institutions emerge, whether institutions are enforced, and what their effect is on economic performance. If the distribution of benefits by a particular institution is not accepted by groups who have high holding power, there would be opposition to the introduction of the institution or its enforcement would be contested, leading to a possible increase in political instability, even though the institution may be growth-enhancing.

Khan's most important contribution to our understanding of the political dynamics of economic growth is the primacy he accords to informal institutions in the beginning of the growth process. Khan argues that the inherited distributional power cannot be supported by the incomes generated by formal institutions alone, and that "informal institutions play a vitally important role in all developing countries because informal institutions are the only feasible mechanism for sustaining economic benefits for powerful groups who would otherwise have lost out" (Khan, 2010, p. 26). The reason why formal institutions play a less important role in growth transitions is that those with holding power will have few of the capabilities that could benefit from protection of property rights and the rule of law, and would therefore have little interest in enforcing these institutions. It is informal institutions, then, that are compatible with the incentive structure of powerful elites, who can use these institutions to have continued access to incomes through "political accumulation."

According to Khan, patron-client networks - informal relationships or organizations that involve individuals with different degrees of power-are likely to provide the institutional context within which credible commitment problems to do with investment can be addressed in an environment where formal institutions of property rights are either not there or are not likely to be enforced. In a typical patron-client network, the patron (who could be a politician or a local mafia, for example) is an organizer of power who organizes group of clients "who offer their organizational support in exchange for the benefits that the patron offers" (Khan, 2010, p. 60). Patron-client networks can operate as informal networks or be within formal organizations such as political parties. Khan suggests that patron-client networks can be organized as pyramids, whereby an individual or faction can be a patron of one network and client of another network. The hierarchical structure of these networks and the elements of control exercised in each level of the pyramid allows for patron-client networks to be self-sustaining and therefore, credible to productive entrepreneurs that the rents from the investment process will not be completely expropriated. Therefore, patrons in the network offer local enforcement and dispute resolution activities to their clients - the investors - in return for political support and the rents that accrue from the production process.

But why do patron-client networks not degenerate into predatory networks, where the level of rent extraction is so high that investors have little incentive to invest, or where patrons expropriate the productive assets of investors. Khan argues that the structure of the ruling coalition is important in explaining why some patron-client networks have greater enforcement capabilities than others. Patron-client networks are likely to be growth oriented when the ruling coalition faces low opposition from excluded factions and lower level factions of the ruling coalition are weakly organized. With limited power from lower level factions, the ruling coalition is able to exercise control across the entire pyramidical structure of the network to make sure that the network does not turn predatory. In this case, patron-client networks can be self-sustaining and growth focused. 
While Khan provides a powerful theory on why patron-client networks can be growth-enhancing, and not degenerate into rent-dissipating entities as often viewed in the literature on economic development (e.g., Krueger, 1974), there are also some limitations in Khan's theory of economic growth. Firstly, it is not clear how the dominant ruling coalition would necessarily be growth oriented. What prevents the coalition not to use its considerable power to use extractive institutions for its own ends and to maintain an optimal rate of rent extraction which may not lead to a growth collapse, but will not lead to stable/miracle growth as well? The ability of the ruling coalition to be growth oriented would depend on the coalition's own long-term self-interest to maximize wealth, or in the vision of long-term development among the elites who constitute the coalition (and therefore, exogenous to Khan's theory). Secondly, it is not clear how the overcoming of coordination failures can take place within patron-client networks when the ability of the state to "pick winners" and to monitor the performance of firms needs a certain degree of bureaucratic capacity, and a relative autonomy of the state from the investor class (Evans, 1995). It is more likely that the character of the political settlement underpinning economic growth changes from one where informal institutions rule to where formal institutions and formal organizations (both an effective economic bureaucracy and well organized and representative business associations) are increasingly important in resolving coordination failures (Bräutignam, Rakner, \& Taylor, 2002).

Thus, Khan's theory of the politics of growth is a more convincing theory of growth acceleration than it is a theory of growth maintenance. Informal institutions and patron-client networks may be crucial in igniting growth and where formal institutional reform may have little growth-enhancing effects. But for growth maintenance, it would be necessary for formal institutions to develop, as well as a more effective bureaucracy, as the political channels of the overcoming of co-ordination failures and the provision of high quality public goods become the primary mechanisms by which political factors determine growth sustenance.

To conclude our review of Acemoglu-Robinson and Khan, we find that there are strong similarities in both theories in their emphasis on political institutions as the key driver of economic growth. However, the theory of Acemoglu-Robinson, with its emphasis on inclusive economic and political institutions, may be more relevant for growth maintenance, while the theory of Mushtaq Khan, with its emphasis on informal institutions and patron-client networks, is more relevant for growth acceleration. Neither Acemoglu-Robinson nor Khan is able to provide a unified theory of understanding the political drivers of growth acceleration as well of growth maintenance/noncollapse.

\section{EMPIRICAL EVIDENCE ON THE POLITICAL DETERMINANTS OF GROWTH TRANSITIONS}

In this section, we review the evidence on the politics of economic growth, and assess the empirical basis of the theoretical framework that we have developed in Section 2 to explain the transition across different growth phases. The propositions that we derived from our theoretical framework were two-fold: firstly, the political drivers of early stage growth accelerations are different from the political drivers of growth maintenance, and secondly, formal institutions of credible commitment and state capacity are unlikely to play a role in growth acceleration (which will be underpinned by informal institutions of credible commitment), but will be more important in the growth maintenance phase.

Among the countries that had a growth acceleration at a relatively early point of their growth experiences, Korea provides an interesting case-study of the differing roles of informal and formal institutions and of state capacity at different phases of economic growth. Both HPR and Berg et al. (2012) identify the year when growth accelerated in Korea to be 1962. Korea is widely regarded as an example of a country (along with Taiwan) with a high effectiveness of the state administrative machinery, which has been seen to be instrumental in its growth success (Amsden, 1989; Wade, 1990). However, as Chang (1998) argues, "Korea and Taipei, China, despite their long Confucian bureaucratic traditions, had rather unimpressive bureaucracies until the late 1960s" (p. 71). As an example of this, Korea was sending its bureaucrats to Pakistan and Philippines for training in administrative skills in the 1960s (Chang, 1998). Evans (1995) also argues that under the tenure of Rhee Syngman, the first President of independent Korea (who was in power from 1948 to 1960), the civil service examinations, the bed-rock of meritocratic appointments in the Korean bureaucracy in later years, was largely by-passed, with only $4 \%$ of those filling higher entry-level positions coming in via civil service examinations. Evans also notes that internal promotions based on merit-an archetypical characteristic of Weberian bureaucracies - were absent in the Rhee regime with higher ranks filled by "special appointments" made by the President, based primarily along clientelistic lines. Patron-client networks between politicians and the business sector were also evident in Korea for much of its early growth period well up to the 1980s with political elites taking "massive donations from the chaebol in return for loans and sweetheart deals" (Kang, 2002). Personal ties between the business elite and the political elite and the mutual advantage that the system of exchanging bribes for political favors to the Korean conglomerates provided to both political and economic elites underpinned informal institutions of credible commitment in Korea all through the 1960s and 1970s, and was crucial for Korea's success in the early stage of growth, in a context where the rule of law in Korea was vague and seldom enforced (Kang, 2002).

While the early impetus for Korea's economic growth came from labor-intensive sectors such as textiles, footwear, wood products, and light manufactures, the Korean state made a conscious attempt in the early 1970s to encourage the growth of high-technology and capital-intensive industries such as basic metals, machinery, electrical and electronic equipment, and chemical products - industries in which Korea was not perceived to have a comparative advantage at its stage of economic development at that time. This was based on the realization among state planners in Korea that without active involvement of the state in overcoming information and spillover related co-ordination failures relating to the acquisition of new capabilities in the production of the more technologically sophisticated products, Korean manufacturers would be "trapped in low return commodity production, (and) excluded from more design-intensive high return products" (Evans, 1995, p. 140). To make the transformation in industrial structure possible, the government supplied investment funds (largely borrowed from abroad) to favored industries at prices below domestic market levels, and successfully moved the economy away from its static comparative advantage specialization in labor intensive commodities to more dynamic products that were increasingly competitive in world markets (Agarwal, Gokarn, Mishra, Parikh, \& Sen, 1995; Amsden, 1989). In addition, the Korean state invested heavily in key 
public goods that were complementary to the push into hightechnology industries, the most important of this being the expansion of high quality technical education through a variety of institutions set up by the Ministry of Science and Technology (Evans, 1995). Therefore, the ability of the Korea state in resolving co-ordination failures relating to technology acquisition as well as providing high quality public goods that were relevant for the growing sectors were important facilitating factors behind the successful structural transformation of the Korean economy in the 1970s and 1980s, and in the maintenance of economic growth.

Another example of the role of informal institutions in early stage growth acceleration is provided by Thailand. The timing of Thailand's early stage growth acceleration as in HPR and Berg et al. (2012) is around 1955-58. Thailand's growth acceleration coincides with the seizure of power by Field Marshall Sarit Thanarat in 1957. Doner and Ramsay (1997) argue that under the Sarit regime, there were strong clientelist relations between Chinese entrepreneurs and local Thai officials based in sectoral Ministries such as Agriculture, Industry, and Commerce as well as the agency established by Sarit to attract foreign capital - the Board of Investment (BOI). These informal relations of credible commitment were not similar to the dense and institutionalized public-private sector ties that characterized state-business relations in Korea and Taiwan but were diffuse, particularistic, and personalized. However, these patron-client networks were growth-enhancing as they discouraged capital flight by encouraging Thai entrepreneurs to invest in patronage, and were competition inducing - as Doner and Ramsay (1997) argue, "with fragmented political patrons eager to obtain extra-bureaucratic funds, clientelism facilitated a constant flow of new private sector claimants on state largesse and thereby weakened tendencies toward the more common result of clientelism-monopoly cronyism" (p. 250). However, by the 1970s, patron-client networks gradually weakened in scope and intensity, with the growth of Thai firms that were relatively autonomous of the political elite and the opening up of the political system with the advent of democratically elected civilian governments that led to the entry of new firms in key sectors of the economy such as rice, sugar, and automobiles (Doner and Ramsay (1997)). Thus, while informal institutions that were largely exclusionary underpinned Thailand's growth acceleration episode in the 1950s, by the 1970s and 1980s, economic and political institutions had become more inclusive and were more conducive to growth maintenance. ${ }^{12}$

Furthermore, in contrast to the 1960s and 1970s, when the BOI promoted mostly traditional industries such as food processing and textiles, there was a clear shift in the 1980 s by the BOI toward the promotion of technology-intensive sectors such as electrical and nonelectrical machinery industries (Agarwal et al., 1995). In addition to investment and export incentives, the BOI helped potential investors (both Thai and foreign) identify promising new projects and find partners for joint ventures. The facilitating role played by the BOI in Thailand's structural transformation (along with the high levels of competence of the bureaucrats in the BOI) was a key factor behind Thailand's ability to maintain economic growth since the 1980s (except for a brief period in the late 1990s, with the onset of the currency crisis in 1997). ${ }^{13}$

Korea and Thailand illustrate the cases of countries which have observed growth acceleration without high levels of bureaucratic capability and the absence of well-functioning formal institutions, but where growth was maintained with the emergence of greater state capacity and more inclusive institutions. In contrast, Indonesia witnessed an early stage growth acceleration in 1967, and had positive economic growth for most years till 1997, but growth collapsed in 1997 following the East Asian financial crisis, with the post1997 growth rate significantly lower than the pre-1997 growth rate (GDP per capita growth in 1967-97 was $4.85 \%$ per annum, while for the period $1997-2010$, it was $2.28 \%$ per annum). Indonesia's growth experience provides a case-study of a country where clientelist relations and informal institutions underpinned the acceleration of growth, but where there was not a sufficiently large move to formal institutions of credible commitment even after three decades of positive growth, and which may have contributed to the growth collapse in the late 1990s.

After the "New Order" government of Suharto came to power in 1965, the proximate causes of economic growth in the first decade and a half of the Suharto regime was sound macroeconomic management, and the promotion of rice agriculture and light industry in the national development plans. State owned enterprises were the dominant corporate force within the economy, making substantial investments in a range of capital and technology intensive industries, such as aircraft and ship-building (Rosser, 2002). The oil boom of the 1970s allowed bureaucrats access to funds that financed the growth of these state enterprises. However, the state intervention of the Suharto regime in the early years of positive economic growth did not resemble the more strategic industrial policies witnessed in Korea, Singapore, and Taiwan, but was principally followed to increase the business clients of the state (Robison, 1986). As Robison and Hadiz (2004, p. 53) argue, "larger strategic objectives were routinely subsumed by the search for extra-budget funding to sustain the political institutions and patronage networks of Indonesia's rules and their own personal enrichment."

With the fall in oil prices in the first half of the 1980s, there was a need to mobilize new sources of investible resources from the private sector as well as to develop export industries, particularly in the manufacturing sector (Rosser, 2002). Thus, the state ownership and public monopolies and the pervasive and protective trade and financial regimes that provided the basis for the patron-client networks that existed between politico-bureaucrats and domestic capitalists in the early stages of economic growth in Indonesia were no longer sustainable in the form they existed prior to the 1980s. In a series of reform packages beginning in the mid-1980s, the Indonesian government deregulated trade and financial regimes, relaxed foreign investment restrictions, and opened a range of former state monopolies to private investment (Hill, 1996). The crisis of the early 1980 could therefore have been the trigger for the emergence of more inclusive economic institutions in Indonesia, as well as the development and enforcement of formal institutions such as competition law and regulations underpinning transactions in financial markets. While some progress was made in this regard, the deregulation process seemed to have further entrenched the emerging "politicobusiness" oligarchies, and patron-client networks that sustained these oligarchies (Robison \& Hadiz, 2004). Thus, the families that owned domestic conglomerates as well as the politico-business class in Indonesia moved into the sectors of the former state monopolies such as banking, finance, and infrastructure. These families also successfully concentrated their presence in sectors that were largely untouched by deregulation such as natural resource industries and domestic trading monopolies. In addition, they diversified their sources of funds from oil revenues to largely unregulated commercial banks' loans and equity in international capital markets. Finally, they preserved their authority over the "strategic gate- 
keeping institutions of the state," ensuring that they maintained control over the allocation of rents. In this way, the patron-client networks that existed between politico-bureaucrats and oligarchic capitalists since the early years of the Suharto regime were significantly strengthened in the 1980s to the early 1990s. The entrenchment of these patron-client networks and "the harnessing of the state to the unconstrained interest of this privileged group of oligarchies" (Robison \& Hadiz, 2004, p. 11) can explain both the nature of the financial crisis in the late 1990s in Indonesia with the widespread bankruptcies and debt defaults among these oligarchs and the stagnation in economic growth in the post-crisis period. Indonesia, therefore, provides a clear example of why economic growth can unravel if informal institutions that underpin early stage growth accelerations remain in place and become predatory in nature as the economy moves further along the growth process.

So far we have reviewed the empirical literature on the politics of economic growth which mostly utilizes case-study and qualitative approaches. To what extent does the vast quantitative literature which utilizes cross-country econometric methods in examining the determinants of economic growth provide support for our theoretical framework? Much of this literature has mostly focused on the determinants of long-run per capita income differences and less on determinants of why countries switch from one growth phase to another. Starting with the seminal piece by Acemoglu, Johnson and Robinson (AJR, 2001), the empirical literature in this tradition shows that institutional quality matters for long-run economic growth, more than other "deep determinants" of economic growth such as geography or culture. However, while measures of institutional or governance quality used in this body of work may be strong, positive correlates of long-run per capita income, they appear to be less important in explaining why some countries experience economic growth and not others. As Khan (2012) notes, for the same level of institutional quality, we see very different growth experiences among developing countries. Since the measures of institutional quality used in the AJR genre captures in essence how well formal institutions are functioning, what the cross-country econometric work in the AJR tradition establishes is the strong positive relationship between the quality of formal institutions and long-run economic growth, but not necessarily of growth transitions within countries. The implication of this literature from our perspective is that while well-functioning formal institutions may not be important determinants of growth accelerations, these institutions may be important in the growth sustenance process, and in the long-run evolution of per capita incomes.

There is now an emerging quantitative literature on the determinants of growth accelerations, and why some countries maintain high growth while other countries witness growth collapses. With respect to growth accelerations, Hausmann, Pritchett, and Rodrik (2005) find that standard growth determinants such as major changes in economic policies, institutional arrangements, political circumstances, or external conditions "do a very poor job of predicting the turning points" (p. 328). They argue that growth accelerations are caused predominantly by idiosyncratic and often, small-scale changes. Jones and Olken (2008) show that changes in institutional quality are not associated with either growth accelerations or declines, where institutional quality is measured by a lower level of corruption and better rule of law. On the other hand, Berg et al. (2012) find that growth duration (that is, the avoidance of growth collapses) is positively related to the presence of democratic political institutions in the country, along with the degree of equality of income distribution. Finally,
Jerzmanowski (2006) finds that better institutional quality improves the possibility that a country will remain in a stable or miracle growth phase and will be less likely to suffer a growth collapse. These findings support our argument that growth accelerations may occur in countries which have weak institutions, but at the same time, weak institutions may limit the sustainability or maintenance of economic growth.

We end this section with presenting our own statistical evidence to provide further empirical support for our arguments. We use a panel data set of 110 countries for which we have International Country Risk Guide (ICRG) time-series data on institutional quality during the period $1984-2010 .{ }^{14}$ First, we estimate a standard growth regression in panel data from where the dependent variable is the annual per capita growth rate of GDP in PPP US constant dollars, and our key explanatory variable is a measure of formal institutional quality, INST, which we obtain by summing four ICRG measures of institutional quality - the protection of property rights, the rule of law, the quality of the bureaucracy, and the control of corruption-for each country and for each year. ${ }^{15}$ Our method of estimation is Ordinary Least Squares, with standard errors corrected for country-level clustering. We use three controls standard in the growth empiric literature-the ratio of government consumption expenditures to GDP (GOVTCONS), the annual inflation rate (INFL) and aid as a ratio of Gross National Income (AID). ${ }^{16}$ Next we estimate the same regression, with country fixed effects included. We then estimate an equation where the dependent variable is a dummy variable which takes the value 1 for the year where the growth acceleration occurred and the two subsequent years, with the same set of controls as in the previous estimates. ${ }^{17}$ Our interest here is to see whether institutional quality plays an important role in growth accelerations. Finally, we estimate an equation where the dummy variable now takes the value 1 for all intervening years between a growth acceleration and a growth decline. ${ }^{18}$ Here, the intention is to see the extent to which formal institutional quality may explain how long a country is in a growth maintenance phase. ${ }^{19}$

We report our results in Table 2. Col. (1) presents a standard growth regression where the dependent variable is annual growth in per capita GDP. Col. (2) presents the same specification, but now with country dummies included. In this case, we are only looking at within-country economic growth, and are controlling for unobserved differences in country characteristics. Col. (3) estimates a growth acceleration equation while Col. (4) estimates a growth maintenance equation. In Col. (1), we find as expected that the quality of institutional quality has a large positive effect on long-run economic growth, as has been found in the previous empirical literature of the AJR genre, with the coefficient on institutional quality (INST) positive and statistically significant at the $1 \%$ level. Introducing country fixed effects in Col. (2) reduces the magnitude of the coefficient on INST from 0.38 to 0.29 but the level of statistical significance remains at $1 \%$. This indicates that Institutional quality is a key determinant of within-country economic growth as it is for cross-country economic growth. In Col. (3), we present the estimates of the possible determinants of growth accelerations. We find that the coefficient on INST becomes statistically insignificant, reinforcing the finding of the quantitative literature on the determinants of growth accelerations that the latter is not associated with an improvement in formal institutional quality Finally, in Col. (4), we present the estimates of the determinants of growth maintenance, and find that formal institutional quality now plays a role in growth maintenance - the coefficient on INST is positive and statistically significant at the $1 \%$ level. ${ }^{20}$ 
Table 2. Regression results

\begin{tabular}{|c|c|c|c|c|}
\hline Independent variables & (1) & (2) & (3) & (4) \\
\hline \multirow[t]{2}{*}{ CONSTANT } & $-1.59^{* *}$ & 1.12 & 0.09 & 0.36 \\
\hline & $(2.00)$ & $(1.15)$ & $(1.16)$ & $(1.52)$ \\
\hline \multirow[t]{2}{*}{ GOVTCONS } & $-0.14^{* * *}$ & $-0.29^{* * *}$ & 0.002 & -0.013 \\
\hline & $(4.76)$ & $(6.52)$ & $(0.85)$ & $(1.48)$ \\
\hline \multirow{2}{*}{ INFL } & $-0.0005^{* * *}$ & $-0.0004^{* * *}$ & $-0.0001^{* *}$ & $-0.0003^{* *}$ \\
\hline & $(2.93)$ & $(3.07)$ & $(2.10)$ & $(2.36)$ \\
\hline \multirow[t]{2}{*}{ AID } & -0.0006 & 0.04 & -0.0004 & 0.011 \\
\hline & $(0.06)$ & $(1.47)$ & $(1.06)$ & $(2.22)$ \\
\hline \multirow[t]{2}{*}{ INST } & $0.38^{* * *}$ & $0.29^{* * *}$ & -0.004 & $0.003^{*}$ \\
\hline & $(6.95)$ & $(5.30)$ & $(1.40)$ & $(1.85)$ \\
\hline Country fixed effects? & No & Yes & No & No \\
\hline$R$-square & 0.11 & 0.24 & 0.06 & 0.08 \\
\hline Number of observations & 1,694 & 1,771 & 1,661 & 925 \\
\hline
\end{tabular}

Notes: The method of estimation is Ordinary Least Square, with standard errors corrected for country-level clustering. The dependent variable in Cols. (1) and (2) is per capita GDP growth in PPP US constant dollars. The dependent variable in Col. (3) is a dummy variable, taking the value one for the year of the growth acceleration, and two subsequent years, zero otherwise. The dependent variable in Col. (4) is a dummy variable, taking the value one for all years between a growth acceleration and a growth decline, zero otherwise. Figures in parentheses are t-ratios.

The level of significance at $10 \%$ respectively.

** The level of significance at $5 \%$ respectively.

The level of significance at $1 \%$ respectively.

These results provide further evidence that improvements in formal institutional quality play an insignificant role in growth acceleration, but matter for the maintenance of economic growth (and the avoidance of growth declines). The empirical analysis we provide in this section is by no means conclusive in the inferences we can draw from it, and further econometric analysis needs to be undertaken, paying particular attention to identification strategies that can isolate the effect of informal institutions on growth acceleration and the possibility of reverse causality from growth maintenance to formal institutional quality. 21

\section{CONCLUSIONS}

In this paper, we assessed what we know about the role of political factors in explaining why some countries grow faster than others. We began with a fresh look at the "stylized facts" of economic growth, and identified an important limitation in the past literature on the stylized facts of growth in that their focus on rates of average growth of per capita income, has obscured the fact most countries observe dramatic fluctuations in growth of per capita income. We suggested that there is a need to shift away from much of the previous literature's emphasis on the determinants of long-run average economic growth (including political determinants), to an understanding of the determinants of switches from one growth phase to another. We proposed that the key question that a research agenda on the political drivers of economic growth must address is an understanding of the political dynamics around the transition from one growth phase to another.

We then developed a conceptual framework for understanding the political dynamics of growth transitions. We discussed three key political channels to economic growth-institutions of credible commitment, the provision of public goods, and the overcoming of coordination failures. We argued that these three channels play out differently across different phases of economic growth. Institutions of credible commitment may be a necessary and sufficient channel to early stage growth accelerations while contributing to growth maintenance as well. Informal institutions of credible commitment may play a more important role in early stage growth accelerations, as opposed to formal institutions which may be more important in growth maintenance. The provision of public goods would be more important in growth maintenance, and can be expected to play a less significant role in growth acceleration. The overcoming of coordination failures would be more important in growth maintenance, though it can also play some role in growth accelerations.

We reviewed two dominant theories of the politics of growth - those of Acemoglu and Robinson and of Khan. Both these theories have strong similarities in their emphasis on institutions being the key drivers of growth, and on the political roots of growth-enhancing or impeding institutions. Both theories take us quite a way forward in enhancing our understanding of the political drivers of growth acceleration and maintenance. However, neither Acemoglu-Robinson nor Khan is able to provide a unified theory of understanding the political drivers of growth acceleration as well of growth maintenance/noncollapse. There is a need for further theoretical development around the explanation of the political transitional dynamics around switches from one growth phase to another that encompass both growth accelerations and growth maintenance.

We then reviewed the empirical basis of our conceptual framework on understanding the political dynamics of economic growth. Our review of country case-studies provided examples of countries such as Korea and Thailand which had witnessed early stage growth accelerations in the absence of formal institutions and high levels of bureaucratic capacity, but where informal institutions around patron-client networks seemed to underpin the growth acceleration process. In both countries, the role of the state in overcoming of co-ordination failures and in the case of Korea, the provision of high quality public goods, were important for growth maintenance. We also discussed the case of Indonesia where the lack of a move away from patron-client networks may explain why growth collapsed, even after several years of positive growth. We also argued that while the cross-country econometric literature on institutions and growth suggest that there is a positive relationship between institutional quality and the long-run level of per capita income, there is less support for the proposition that better formal economic and political institutions are either necessary or sufficient to obtain growth accelerations. 
Our review of the emerging quantitative literature on the determinants of growth accelerations and growth maintenance supports this conclusion-these studies find that reforms in formal economic institutions do not seem to be associated with growth accelerations. However, this literature also finds that a country which has witnessed growth acceleration is more likely to stay in a high growth phase and not suffer a growth decline if better quality formal institutions were to emerge in the growth process. Finally, we presented statistical evidence drawn from a cross-country econometric analysis of growth acceleration and growth maintenance that further reinforces our main proposition that the institutional determinants of growth accelerations are different from that of growth maintenance.

Both our review of the theoretical and empirical literature as well as the statistical evidence that we provide in this paper supports our key proposition that the political drivers of early stage growth acceleration are different from the political drivers of growth maintenance. However, the empirical evidence we present in the paper is suggestive and not conclusive of our main arguments on the different roles that political channels to growth - informal and formal institutions of credible commitment, the provision of public goods and the overcoming of co-ordination failures-play across different phases of economic growth. From a theoretical standpoint, we need to understand better why patron-client networks are growthenhancing in some countries and growth impeding in others. We also need to understand some countries are able to move from informal to formal institutions of credible commitment and others are not able to make this transition, and why political elites have an incentive to invest in state capacity that allows for the provision of high quality public goods and the overcoming of co-ordination failures in some country contexts and not in others. From an empirical standpoint, we need more structured comparative case-studies of countries which have witnessed a growth acceleration versus countries which have not, and of countries where growth once started has not collapsed versus countries which have observed an acceleration in growth only to see it decline it later, to establish how the political channels to growth differed in their effects on growth in these countries and across growth phases. We also need more robust econometric evidence of the political drivers of economic growth that can explain both the political determinants of growth accelerations as well of growth maintenance and growth collapse, and that captures the high volatility of economic growth within countries and over time.

The literature on the determinants of economic growth has moved a long way from being pre-occupied by proximate determinants of growth to more fundamental causes such as economic institutions, which in turn are increasingly seen to be shaped by political factors. The task of future research in this area should be to better understand why it is rare to see growth episodes being sustained in the developing world, and how political processes and institutions can explain the differential success that developing countries have, both in igniting economic growth and in transforming growth accelerations to growth sustenance.

\section{NOTES}

1. In the first systematic analysis of growth accelerations, Hausmann, Pritchett and Rodrik (HPR) (2005) study such episodes of growth accelerations for all countries, developed and developing, since the 1950s, and identify an episode of growth acceleration by the following three conditions: (i) where the least squares growth rate is greater or equal to $3.5 \%$ per annum; (ii) where the change in the least squares growth exceeds $2 \%$ per annum over a 8 year time horizon; and (iii) where post-change growth output exceeds the pre-episode peak. (1) Using these criteria, HPR identify 83 episodes of growth accelerations during 1957-92, the starting and ending years of their analysis. They find episodes of growth accelerations in all regions of the world, and the average acceleration in per capita income is $4.7 \%$ per annum, implying that in the typical episode, output was almost $40 \%$ higher at the end of episode than it would have been without the growth acceleration. The large number of episodes observed by HPR and the magnitude of changes in per capita incomes in the average episode provides a strong justification why it is important to move beyond accounts of long-run growth to within-country growth episodes in any examination of the causes of economic growth. HPR observe that a typical country would have about $25 \%$ chance of experiencing a growth transition at some point in any given decade. It is also worth noting that the largest number of growth accelerations is in Africa (20 episodes, using the HPR criteria), a continent that is not usually associated with economic growth.

2. A more comprehensive classification of growth phases than the one provided here is offered by Pritchett (2000), who attempts to identify single break-points in the per capita income time-series of developed and developing countries using a simple rule of thumb statistical procedure for the period 1960-92 (not all countries in Pritchett's sample had data till 1992). He then demarcates six distinct growth phases, based on the identification of the break-point: (i) Steep Hills-where growth rates were $3 \%$ or higher in pre and post-break periods; (ii) Hills - where growth rates were higher than $1.5 \%$ in pre and post-break periods; (iii) Plateaus-where growth rates were higher than $1.5 \%$ in the pre-break period but fell to less than $1.5 \%$ in the post-break period; (iv) Mountains - where growth rates were higher than $1.5 \%$ in their trend beak but fell to negative rates afterward; (v) Plains - where growth rates were less than $1.5 \%$ in pre and post-break periods; and (vi) Accelerators - where growth rates were less than $1.5 \%$ before the break, and higher than $1.5 \%$ after the break. While Pritchett's criteria to identify growth phases is fairly rudimentary, an emerging literature has begun to identify the exact timing of growth phase switches and the duration that a particular country stays in a particular growth phase using more sophisticated modern time-series methods. Example of the application of such methods are Jones and Olken (2008) and Berg, Ostry, and Zettelmeyer (2012) who use variants of the procedure proposed by Bai and Perron (1998) to identify multiple breaks in the per capita income series when the total number and timing of structural breaks is unknown, and by doing so, allow a country to be in multiple growth phases over time (in contrast to Pritchett, whose method only allows for two growth phases - one before and one after the single break in the per capita income series). Furthermore, these studies that utilize the Bai-Perron method are more suitable than HPR for most developing country GDP data as the latter method can address nonstationarity in the GDP data which Pritchett (2000) and HPR cannot. Jerzmanowski (2006) and Kerekes (2012) use Markov switching regression models to estimate the probability of transition from one growth phase to another for countries with different chararacteristics. More details of these studies are provided in our discussion of the empirical literature on the politics of economic growth.

3. An extensive literature has examined whether the type of political regime - democracy versus autocracy - is causal to economic growth (e.g., Acemoglu, Johnson, Robinson, \& Yared 2008). We do not see political regime type as a separate political channel to growth, independent of the ones we identify here. There is no intrinsic characteristic of a democracy or of an autocracy that makes a particular growth phase (acceleration/ maintenance/collapse) more likely to occur than any other growth phase. However, the political regime type may condition the manner a specific 
political channel to growth may operate-for example, in a multi-party democracy, where parties alternate in power, the short-termism of politicians may not allow for the emergence of sustaining patron-client networks which facilitate growth accelerations. We discuss the implications of political regime type in greater details when we discuss the theories of Acemoglu and Robinson, and Khan in Section 4 of the paper.

4. For an intuitive exposition to the commitment problem and a discussion of the various solutions to this problem, see Bardhan (2005, chap. 2).

5. As Haber, Razo, and Maurer (2003) argue, the theoretical optimal solution to the credible commitment problem is limited government, in which the state respects property rights as a matter of law, and politicians cannot arbitrarily change laws that constrain them. However, for limited government to function as an effective mechanism to ensure credible commitment on the part of the state, one needs a set of well-functioning formal institutions that govern decision making and punish errant behavior on the part of politicians. These set of institutions are unlikely to be present in early stage growth accelerations. Patron client networks, which take the form of "repeated games" between politicians and investors can be seen as a second-best solution to the credible commitment problem, as they are inherent unstable and depend on the politician's own volition not to engage in predatory or opportunistic behavior at any point of the repeated game. This also explains why self-sustaining growth oriented patron-client networks are rare to observe in most countries where the state is despotic or in conflict-ridden country contexts where the time horizon of both politicians and investors is short. We would expect that in such contexts, growth accelerations would be unlikely to occur (as few as four out of the 83 growth accelerations identified by HPR have occurred in countries which the World Bank considers as fragile, with a CPIA score of less than 3.0, these being the Republic of Congo and Guinea-Bissau

6. We take public goods here as being not only pure public goods (in that they are nonexcludable and nonrival) but also club goods (in that they are not nonrival but are nonexcludable) and quasi-public goods (in that they are nonrival but are excludable). While education can be both rival and excludable, we take it to be a public good as human capital can have significant positive externalities (Lucas, 1988).

7. However, not all public goods need a critical level of bureaucratic professionalism for their provision, and it is possible that some local public goods which may be important for growth take-offs such as the creation of an export processing zone or an industrial estate (that allows for pockets of growth to develop in the economy) and the infrastructure associated with these public goods can be provided even when bureaucratic capacity is not well developed, and within clientelist and neopatrimonial contexts (Kelsall, Booth, Cammack, \& Golooba-Mutebi, 2010).

8. What explains why political elites in some countries are willing and able to invest in state capacity that brings about structural transformation and the maintenance of economic growth, and why elites in many countries choose not to do so? Besley and Persson (2011) argue that when elites have strong common interests, they have more of an incentive to invest in state capacity. They argue that strong common interests are more likely to come about when there is an external threat to the country or because cross-cutting cleavages in society are weak enough not to result in political and economic polarization that lower the incentives of elites to invest in public goods such as the legal and the fiscal capacity of the state.

9. The causes of later stage growth accelerations would be different from those of early stage growth accelerations. We would observe such growth accelerations when the country has already had a period of positive growth previously. In such a context, formal institutions such as wellfunctioning courts which protect and enforce property rights would have emerged as well as greater administrative capacity of the state. For later stage growth accelerations, informal institutions of credible commitment would play less of a role in re-igniting growth that in the case of early stage growth accelerations. Furthermore, the likelihood of economic growth returning will be greater, the higher the increase in the quality of the institutions and the greater the improvement in the quality of bureaucracy in the positive growth phase preceding the growth decline.

10. A recent influential contribution on the causes of different levels of economic and political development across countries is North, Wallis, and Weingast (2009). We do not review North, Wallis and Weingast here as the focus of their work is on the long-term historical roots of economic progress, especially in Western societies, and they do not provide a theory of economic growth. It should be noted, however, that there are common elements between their theory of economic development and those of Acemoglu-Robinson and Khan.

11. It should be noted that AR is careful not to equate inclusive political institutions with democracy, though clearly the latter can be considered to be a sub-set of the former set of institutions.

12. Our examples of the role of informal institutions underpinning growth accelerations have been drawn from Asia, where there is a large literature on the politics of economic growth. In contrast, we have relatively few accounts of the politics underpinning growth acceleration episodes from Africa. Two exceptions are Bräutignam et al. (2002) which highlight the role of "growth coalitions"-coalitions of business and political elites that are underpinned by synergistic relations and which mobilize institutions and resources for economic growth - in explaining the growth success of Mauritius, and Abdel-Latif and Schmitz (2010), in their study of the political determinants of sectoral differences in investment and growth outcomes in Egypt, who show that informal alliances between business and politicians, built around strong social ties, and based on common interest in the sector's growth and a common understanding of the sector's problems, can explain why there were positive investment and growth outcomes in some sectors in Egypt and not in others. These studies provide further support for the proposition that informal institutions in the form of loose and informal alliances between politicians and investors, are more important in growth accelerations in country contexts where improvements in formal institutions around better rule of law and property rights systems may take time to achieve.

13. As Warr (2011) notes, not a single year of negative growth of real output per capita was experienced by the Thai economy in 1958-86, a unique achievement among oil-importing developing countries.

14. ICRG is the main source for institutional quality time-series data for a sufficiently large number of countries. The period of our empirical analysis is constrained by the availability of annual ICRG data on institutional quality only for the years from 1984 to 2010 .

15. A vast number of studies have used these measures in testing for the effects of institutions on economic growth. Prominent among them are Hall and Jones (1999), Acemoglu et al. (2001), Glaeser, La Porta, Lopez-deSilanes, and Shleifer (2004), and Rodrik, Subramanian, and Trebbi (2004).

16. Human capital or years of schooling is also used as a determinant of economic growth in most growth regressions. However, the data are only available quinquennially, and given the short time-series dimension of the panel data, is mostly insignificant in the estimates. Hence, we did not include it in the final set of results.

17. We obtain the years for growth accelerations and growth declines from Berg et al. (2012). HPR do not provide information on growth declines, which is why we only used Berg et al. (2012) in our analysis. However, by including the two subsequent years following the year of the growth acceleration in the construction of the dummy variable for growth acceleration, we have effectively included most of the HPR break years, as the latter differ from Berg 
et al. (2012) by a year or two for most countries that are common to both studies. Note that in the specific definition of growth maintenance that we use from Berg is that the country needs to be in a growth maintenance phase for at least 8 years. By doing so, we differentiate growth maintenance and growth decline from purely cyclical movements in GDP per capita.

18. If there was no growth decline for a particular country in the period 1984-2010, all years following a growth acceleration takes the value 1, 0 otherwise, for all years till 2010.

19. In the results we present in Table 2 for Cols. (3) and (4), we did not include country fixed effects. Our results are identical with the country fixed effects included for the growth acceleration and growth maintenance regressions, except that the institutional quality variable is now negative and significant at the $5 \%$ level for growth acceleration.

20. The coefficients on Government Consumption, Inflation, and Aid are of the right sign-greater government consumption and higher inflation leads to lower growth and higher aid leads to higher growth - and are generally statistically significant. We also did two more robustness tests, to allow for different specifications of growth acceleration and growth maintenance variables. In the first robustness test, we coded growth acceleration only for the year for which the acceleration has occurred. In the second robustness test, we kept the growth acceleration variable as in the original specification, and specified the growth maintenance variable as taking the value 1 for all years, except the 2 years after the acceleration. When we re-did the regressions in Col. (3) and Col. (4), our results on the insignificance of the institutional variable for growth acceleration and its positive and significant effect on growth maintenance did not change.

21. One potentially promising way of testing for the effects of informal institutions on growth accelerations is to find natural experiments from historical episodes where patron-client networks may change with the death of a leader, and to isolate the effect of this change on economic growth. Jones and Olken (2005) provide an interesting example of such a natural experiment by using death of leaders as a source of exogenous variation in the character of the ruling elite and find robust evidence that such a change in the ruling elite matters for economic growth. This does not provide conclusive evidence on the importance of patron-client networks in growth accelerations, but suggests that the death of a leader may trigger changes in patron-client networks that have an impact on economic growth.

\section{REFERENCES}

Abdel-Latif, Abla, \& Schmitz, Hubert (2010). Growth alliances: Insights from Egypt. Business and Politics, 12(4), 1-27.

Acemoglu, Daron (2009). Introduction to modern economic growth. Princeton: Princeton University Press.

Acemoglu, Daron, \& Robinson, James (2008). The role of institutions in growth and development. Working paper no. 10. Commission for Growth and Development, Washington, D.C.

Acemoglu, Daron, Johnson, Simon, \& Robinson, James (2001). The colonial origins of comparative development. American Economic Review, 91, 1369-1401.

Acemoglu, David, Johnson, Simon, \& Robinson, James (2005). Institutions as the fundamental cause of long-run growth. In P. Aghion, \& S. Durlauf (Eds.), Handbook of economic growth. Amsterdam: NorthHolland.

Acemoglu, Daron, Johnson, Simon, Robinson, James, \& Yared, Pierre (2008). Income and democracy. American Economic Review, 98(3), 808-842.

Acemoglu, Daron, \& Robinson, James (2012). Why nations fail: The origins of power, prosperity and poverty. New York: Random House.

Agarwal, Pradeep, Gokarn, Subir, Mishra, Veena, Parikh, Kirit S., \& Sen, Kunal (1995). Economic restructuring in East Asia and India: Perspectives on policy reform. London: Macmillan.

Amsden, Alice (1989). Asia's next giant: South Korea and late industrialisation. New York: Oxford University Press.

Bai, Jushan, \& Perron, Pierre (1998). Estimating and testing linear models with multiple structural change. Econometrica, 66, 47-78.

Bardhan, Pranab (2005). Scarcity, conflicts and cooperation: Essays in the political and institutional economics of development. Cambridge MA: The MIT Press.

Barro, Robert (1991). Economic growth in a cross-section of countries. Quarterly Journal of Economics, 106(2), 407-443.

Benhabib, Jess, \& Speigel, M. M. (1994). The role of human capital in economic development: Evidence from aggregate cross-country data. Journal of Monetary Economics, 34(2), 143-174.

Berg, Andrew, Ostry, Jonathan, \& Zettelmeyer, Jeromin (2012). What makes growth sustained?. Journal of Development Economics, 98(2), 149-166.

Besley, Timothy, \& Persson, Torsten (2011). Pillars of prosperity: The political economics of development clusters. Princeton: Princeton University Press.

Bloom, David, Canning, D., \& Sevilla, J. (2004). The effect of health on economic growth: A production function approach. World Development, 32(1), 1-13.

Bräutignam, Deborah, Rakner, L., \& Taylor, S. (2002). Business associations and growth coalitions in Sub-Saharan Africa. Journal of Modern African Studies, 40(4), 519-547.

Commission for Growth and Development (CGD) (2008). The growth report: Strategies for sustained growth and inclusive development. The World Bank, Washington, D.C.
Chang, Ha-Joon (1998). The role of institutions in Asian development. Asian Development Review, 16(2), 64-95.

Dixit, Avinash (2009). Governance institutions and economic activity. American Economic Review, 99(1), 5-24.

Dixit, Avinash, \& Pindyck, Robert (1994). Investment under uncertainty. Princeton: Princeton University Press.

Doner, Richard, \& Alvin, Ramsay (1997). Competitive clientelism and economic governance: The case of Thailand. In Maxfield Sylvia, \& Schneider Ben Ross (Eds.), Business and the state in developing countries (pp. 237-276). Ithaca: Cornell University Press.

Evans, Peter (1995). Embedded autonomy: States and industrial transformation. Princeton: Princeton University Press.

Evans, Peter (2011). Constructing the 21 st century developmental state. Mimeo.

Evans, Peter, \& Rauch, James (1999). Bureaucracy and growth: A crossnational analysis of the effects of the "Weberian" state. American Sociological Review, 64(5), 748-763.

Glaeser, Edward, La Porta, Rafael, Lopez-de-Silanes, Florencio, \& Shleifer, Andrei (2004). Do institutions cause growth?. Journal of Economic Growth, 9, 271-303.

Grief, Avner (2006). Institutions and the path to the modern economy: Lessons from medieval trade. Cambridge: Cambridge University Press.

Haber, S., Razo, A., \& Maurer, N. (2003). The politics of property rights: Political instability, credible commitment and economic growth in Mexico, 1876-1929. Cambridge: Cambridge University Press.

Hall, Robert, \& Jones, Charles I. (1999). Why do some countries produce so much output per worker than others?. Quarterly Journal of Economics, 114, 83-116.

Hausmann, Ricardo, Pritchett, Lant, \& Rodrik, Dani (2005). Growth accelerations. Journal of Economic Growth, 10, 303-329.

Hill, Hal (1996). The Indonesian economy since 1966: Asia's emerging giant. Cambridge: Cambridge University Press.

Hoff, Karla (2000). Beyond Rosenstein-Rodan: The modern theory of underdevelopment traps. Mimeo.

Jerzmanowski, M. (2006). Empirics of hills, plateaus, mountains and plains: A Markov-switching approach to growth. Journal of Development Economics, 81, 357-385.

Jones, B., \& Olken, B. (2005). Do leaders matter? National leadership and growth since World War II. Quarterly Journal of Economics, August, 835-864.

Jones, Ben, \& Olken, Ben (2008). The anatomy of start-stop growth. Review of Economics and Statistics, 90(3), 582-587.

Kang, David (2002). Bad loans to good friends: Money politics and the developmental state in South Korea. International Organization, 56(1), 177-207.

Kelsall, Tim, Booth, David, Cammack, Dianne, \& Golooba-Mutebi, Fred (2010). Development patrimonialism? Questioning the orthodoxy on 
political governance and economic progress in Africa. Working paper no. 9. Africa Power and Politics Programme.

Kerekes, Monika. (2012). Growth miracles and failures in a Markov switching classification model of growth. Journal of Development Economics, 98(2), 167-177.

Khan, Mushtaq (2010). Political settlements and the governance of growth-enhancing institutions. School of oriental and asian studies working paper. Available from http://eprints.soas.ac.uk/9968/ (accessed on April 1, 2012).

Khan, Mushtaq (2012). Governance and growth: History, ideology and methods of proof. In A. Noman, K. Botchwey, H. Stein, \& J. Stiglitz (Eds.), Good growth and governance in Africa (pp. 51-79). Oxford: Oxford University Press.

Krueger, Anne O. (1974). The political economy of the rent-seeking society. American Economic Review, 64(3), 291-303.

Lin, Justin Yifu and Monga, Celestin (2010). Growth identification and facilitation: The role of the state in the dynamics of structural change. World Bank policy working paper no. 5313. Washington, D.C.

Lucas, Robert E. Jr., (1988). On the mechanics of economic development. Journal of Monetary Economics, 22, 3-42.

Murphy, Kevin, Shleifer, Andrei, \& Vishny, Robert W. (1989). Industrialisation and the big push. Journal of Political Economy, 97(5), $1003-1026$.

North, Douglass C. (1990). Institutions, institutional change, and economic performance. New York: Cambridge University Press.

North, Douglass C., \& Thomas, Robert P. (1973). The rise of the Western World: A new economic history. Cambridge: Cambridge University Press.

North, Douglas N., Wallis, Joseph J., \& Weingast, Barry R. (2009). Violence and social orders. Cambridge: Cambridge University Press.

Pedroni, P., \& Canning, D. (2008). Infrastructure long run economic growth and causality tests for cointegrated panels. The Manchester School, 76, 504-527.

Pindyck, R. S. (1991). Irreversibility, uncertainty and investment. Journal of Economic Literature, 29, 1110-1148.
Pritchett, Lant (2000). Understanding patterns of economic growth: Searching for hills among plateaus, mountains and plains. World Bank Economic Review, 14(2), 221-250.

Robison, R. (1986). Indonesia: The rise of capital. London: Allen and Unwin.

Robison, R., \& Hadiz, V. (2004). Reorganising power in Indonesia: The politics of oligarchy in an age of markets. London: Routledge Curzon.

Rodrik, Dani (1991). Policy uncertainty and private investment in developing countries. Journal of Development Economics, 36, 229243.

Rodrik, Dani, Subramanian, A., \& Trebbi, F. (2004). Institutions rule: The primacy of institutions over geography and integration in economic development. Journal of Economic Growth, 9, 131-165.

Rosenstein-Rodan, Paul N. (1943). Problems of industrialisation in Eastern and South-Eastern Europe. The Economic Journal, 53(210/ 211), 202-211.

Rosser, Andrew (2002). The politics of economic liberalisation in Indonesia. Richmond: Curzon.

Sachs, Jeffrey (2003) Institutions don't rule: Direct effects of geography on per capita income. NBER working paper no. 9490.

Soifer, H. (2008). State infrastructural power: Approaches to conceptualisation and measurement. Studies in Comparative International Development, 43, 231-251.

Strauss, John, \& Thomas, Duncan (1998). Health nutrition and economic development. Journal of Economic Literature, XXXVI, 766-817.

Wade, Robert (1990). Governing the market: Economic theory and the role of government in East Asian industrialisation. Princeton: Princeton University Press.

Warr, Peter (2011). Thailand's development strategy and growth performance. UNU/WIDER working paper no. 2011/02.

Whitfield, Lindsay and Therkildsen, Ole (2011). What drives states to support the strategies of productive sectors? Strategies ruling elites pursue for political survival and their policy implications. DIIS working paper no. 15. 